\title{
Structural and histochemical profile of Lopesia sp. Rübsaamen 1908 pinnula galls on Mimosa tenuiflora (Willd.) Poir. in a Caatinga environment
}

\author{
Ravena Malheiros Nogueira ${ }^{1}$, Elaine Cotrim Costa $^{2}$, Juliana Santos Silva ${ }^{1}$ and \\ (iDosy Mary dos Santos Isaias ${ }^{2,3}$
}

Received: 23.10.2017; accepted: 2.04.2018

\begin{abstract}
Structural and histochemical profile of Lopesia sp. Rübsaamen 1908 pinnula galls on Mimosa tenuiflora (Willd.) Poir. in a Caatinga environment). Gall-inducing insects can change the anatomical pattern of host plant tissues by inducing peculiar gall morphotypes. In this study, the structural changes observed in Lopesia galls on Mimosa tenuiflora resemble those found in other Cecidomyiidae, with two tissue compartments. Nevertheless, the parenchyma layers of the inner compartment, between the mechanical zone and the nutritive tissue, are peculiar. Gall development does not impair the synthesis of any compounds detected by histochemical tests on non-galled tissues of $M$. tenuiflora. Lignin, polyphenols, alkaloids and terpenoids were detected in the outer compartment, suggesting their involvement in chemical defence of galls. Proteins, reducing sugars and lipids were detected both in outer and inner compartments, whereas nutritive tissue is rich in reducing sugar. This profile is linked with the nutrition of the gall-inducing insect. The Caatinga environment does not seem to constrain the development of galls, but the thick periclinal cell wall and homogeneous parenchyma may contribute to the control of humidity and light radiation, thus favouring the survival of the gall-inducing insect.
\end{abstract}

Keywords: Cecidomyiidae, gall anatomy, leaf gall, plant insect interaction

RESUMO - (Perfil estrutural e histoquímico de galhas foliares de Lopesia sp. Rübsaamen 1908 em Mimosa tenuiflora (Willd.) Poir. em ambiente de Caatinga). Insetos galhadores podem alterar o padrão anatômico dos tecidos das suas plantas hospedeiras, induzindo morfotipos peculiares de galhas. Neste estudo, as modificações estruturais observadas nas galhas de Lopesia sp. em Mimosa tenuiflora assemelham-se àquelas evidenciadas em outras galhas de Cecidomyiidae, com dois compartimentos teciduais. No entanto, as camadas de parênquima no compartimento interno entre a zona mecânica e o tecido nutritivo são peculiares. O desenvolvimento da galha não bloqueia a síntese de quaisquer compostos detectados nos tecidos não galhados de M. tenuiflora, por meio de testes histoquímicos. Ligninas, polifenóis, alcaloides e terpenoides foram detectados no compartimento externo, sugerindo seu envolvimento na defesa química das galhas. Proteínas, açúcares redutores e lipídios foram detectados tanto no compartimento externo quanto no interno, e o tecido nutritivo é rico em açúcares redutores. Esse perfil está ligado à nutrição do galhador. $\mathrm{O}$ ambiente da Caatinga parece não impor restrições ao desenvolvimento da galha, mas, a parede celular periclinal espessa e o parênquima homogêneo parecem contribuir para o controle da umidade e da radiação, favorecendo à sobrevivência do inseto galhador.

Palavras-chave: anatomia de galha, Cecidomyiidae, galha foliar, interação inseto-planta

\section{Introduction}

All plant groups may be attacked by mites, nematodes, bacteria, fungi, viruses, lichens, and mostly by insects, resulting in the development of galls (Mani 1964, Rohfritsch 1992). Galls are the result of abnormal growth of plant tissues due to an increase in the cell hypertrophy and cell division induced by the feeding stimuli of the galling insects (Raman 2007). These structural changes and the physiology of the host plant cells and tissues are redirected toward a new organ, the gall (Harper et al. 2004, Raman 2007).

1. Universidade do Estado da Bahia, Departamento de Educação, Programa de Pós-Graduação em Biodiversidade Vegetal, Rua da Gangorra, 503, CHESF, 48608-240 Paulo Afonso, BA, Brasil

2. Universidade Federal de Minas Gerais, Instituto de Ciências Biológicas, Departamento de Botânica, Programa de Pós-Graduação em Biologia Vegetal, Campus UFMG, Avenida Presidente Antônio Carlos, 6627, 31270-901 Belo Horizonte, MG, Brasil

3. Corresponding author: rosy@icb.ufmg.br 
Among the most common family of insects capable of inducing galls, the one most representative is the Cecidomyiidae (Diptera) (Gagné \& Jaschhof 2017).

An important aspect of the Cecidomyiidae is that they induce profound modifications in their host plant organs, both at the cell and tissue levels (Arduin \& Kraus 1995, Moura et al. 2009, Oliveira \& Isaias 2010, Isaias et al. 2011). After the establishment of the galling insect, the growth of gall tissues is associated with changes in the accumulation of carbohydrates, proteins, lipids, as well as secondary metabolites, such as phenols and alkaloids (Arya et al. 1975, Oliveira et al. 2011, Amorim et al. 2017, Bragança et al. 2017). Accordingly, the histolocalization of these compounds is related to the nutrition of the galling insect, as well as to the defense against natural enemies and unfavorable environmental factors (Stone \& Schönrogge 2003). Consequently, the metabolites may be compartmentalized in gall tissues (Bragança et al. 2017).

A common species of LeguminosaeCaesalpinioideae, Mimosa tenuiflora (Willd.) Poir. is infested by a galling Lopesia Rübsaamen 1908 (Cecidomyiidae) in the Caatinga vegetation in the Northeast region, Brazil (Maia et al. 2010, Santos et al. 2011, Carvalho-Fernandes et al. 2012). Mimosa tenuiflora occurs in Brazil, Colombia, El Salvador, Honduras, Mexico, and Venezuela. In Brazil, it has been recorded in all states of the Northeast region, extending to the State of Minas Gerais, and is one of the best-studied species of Fabaceae. Its anatomy, ecology, chemical constituents, biological activity, and usages have been addressed in more than 30 scientific publications ( $c f$. Santos-Silva et al. 2015), reflecting its large economic and ecological importance.

The adaptive success of $M$. tenuiflora in Caatinga environment may be related to its anatomical traits. Among the adaptive traits commonly related to xeric environments, a reduction in volume-surface ratio, thick wax, cuticle and periclinal cell walls, dense palisade parenchyma and trichome covering, and abundant water storage tissues (Fahn \& Cutler 1992) can be expected in both host leaves and galls. Phenolics and calcium oxalate crystals may also occur (Fahn \& Cutler 1992, Fahmy 1997, Burrows 2001, Rotondi et al. 2003). This work analyzes the M. tenuiflora-Lopesia sp. system as a model of study to map traits that may favor plant survival over the abiotic peculiarities of the Caatinga, and that can be overexpressed during gall development.
Herein, we address a new approach for this plant species, focusing on its structural and histochemical profiles developed under the influence of the associated galling insect, Lopesia sp. Moreover, we discuss structural and histochemical profiles of Lopesia galls under the influence of abiotic and biotic stresses, such as high temperatures and natural enemies, in the Caatinga environment. It is assumed that the gall-inducing insect stimuli, together with the environmental stress, should drive the morphogenesis of the gall toward anatomical and chemical traits that could induce positive responses to the adaptive value of both $M$. tenuiflora and the galling Lopesia $\mathrm{sp}$. The main question is: can the characteristics of Caatinga vegetation impact both the structural and histochemical profile of the galls induced by Lopesia sp. on M. tenuiflora?

\section{Materials and methods}

Sampling and Fixation - Non-galled pinnulae and galls were randomly sampled from individuals of M. tenuiflora $(\mathrm{n}=10)$ located at Lagoa Rasa Ranch ( $13^{\circ} 95^{\prime} \mathrm{S}$ e $\left.42^{\circ} 47^{\prime} \mathrm{W}\right)$, Cachoeirinha Farm, Caetité municipality, Bahia State, Brazil. The voucher specimen is deposited at HUNEB herbarium under the registration number 24.975 .

Anatomical analysis - Samples $(\mathrm{n}=5)$ of non-galled pinnula, mature, and senescent galls were fixed in FAA (37\% formaldehyde, glacial acetic acid, and $50 \%$ ethanol, 1:1:18, v/v) for 48 hours, dehydrated in an ethanol series, embedded in Paraplast ${ }^{\circledR}$ (Kraus \& Arduin, 1997), and cross-sectioned $(12 \mu \mathrm{m})$ in a Reichert Jung ${ }^{\circledR}$ rotary microtome. The histological sections were stained with $0.5 \%$ safranin and $0.5 \%$ astra blue, 9:1, v/v (Kraus \& Arduin 1997).

Histochemical analysis - Handmade sections $(n=5)$ of fresh non-galled pinnulas, mature and senescent galls were used for histochemical analyses. For detection of proteins, the sections were immersed in $0.1 \%$ bromophenol blue in a saturated solution of magnesium chloride in ethanol during 15 minutes, and later washed in acetic acid and water (Backer 1958). For reducing sugars, the sections were immersed in Fehling's reagent (solution A- 7.9\% copper sulphate and solution B- $34.6 \%$ potassium sodium tartrate and $1 \%$ sodium hydroxide, followed by heating) for 15 minutes (Sass 1951). The presence of lipids and starch was verified with saturated solution of Sudan red B in 70\% ethanol for 20 minutes (Brundett 
et al. 1991), and with Lugol's reagent for 5 minutes (Johansen 1940). For detection of lignins, acidified phloroglucinol (solution A- 2\% phloroglucin and solution B-25\% hydrochloric acid) was applied for 5 minutes (Johansen 1940). For detection of polyphenols, $1 \%$ ferric chloride was used for 5 minutes (Johansen 1940). The accumulation of alkaloids was verified with Jeffrey's reagent (10\% nitric acid and $10 \%$ chromic acid), for 15 minutes (Johansen 1940), and terpenes were detected with $1 \% \alpha$-naphthol and $1 \%$ dimethyl- $p$-phenylenediamine (NADI reagent) in $0.01 \mathrm{M}$ phosphate buffer, $\mathrm{pH} 7.2$, for 30 minutes (David \& Carde 1964). The sections were mounted in Kaiser's jelly glycerin (Kraus \& Arduin 1997). All reactions were followed by control tests according to the authors, compared to blank sections, and photographed on a light microscope (Leica ICC50 HP).

\section{Results}

General aspects of host plant and gall morphology M. tenuiflora is a tree (figure 1), approximately $8 \mathrm{~m}$ high. Its leaves are compound twice-pinnate with 4-10 pairs of leaflets, and 17-25 pairs of pinnula per leaflet (figure 2). The leaflets are papery, oblong with entire margins, oblique base and rounded apex, glabrous to pilosulous, with minute sessile glands especially on the abaxial surface (Santos-Silva et al. 2015). Lopesia sp. galls on M. tenuiflora are unilocular, covered with sparse non-glandular trichomes. The galls are bivalveshaped, non-fused along the margins, and turn from green to brown along development (figure 3).

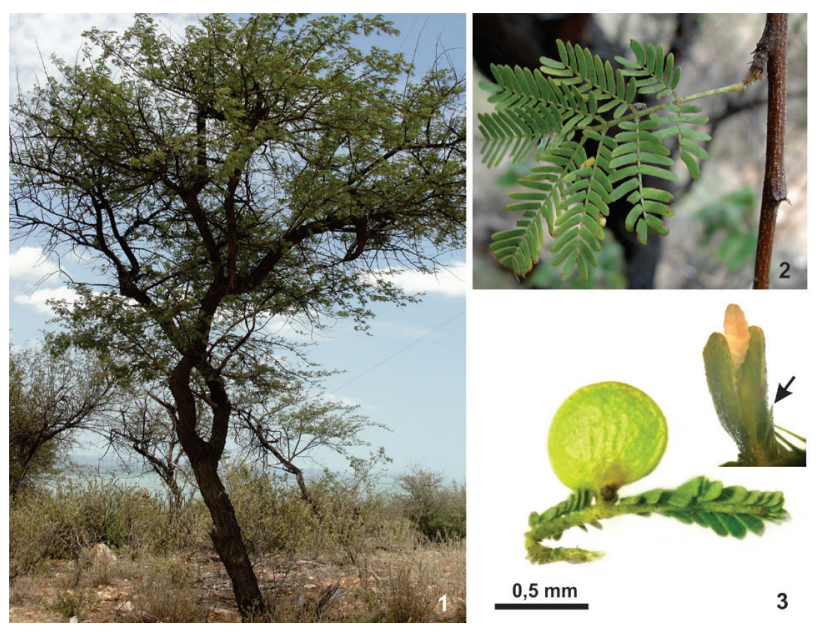

Figure 1-3. Mimosa tenuiflora (Leguminosae - Caesalpinioideae) non-galled pinnula and galls of Lopesia sp. (Cecidomyiidae Diptera). 1. Plant habit 2. Leaf. 3. Leaflet with bivalve-shaped gall, evidencing the pinnula at the base of valves (arrow).
Anatomical and histochemical profiles of the nongalled pinnula - The epidermis is uniseriate, with irregular shaped cells, thick-walled and covered by thin cuticle both on adaxial and abaxial surface. Pinnula lamina is dorsiventral, with a 3-layered palisade parenchyma and a 3-4 layered spongy parenchyma (figure 4). The unicellular non-glandular trichomes (figure 5) vary in size, and are straight, with sharp apex. Multicellular glandular trichomes occur (figure 6) in adaxial and abaxial surfaces. The vascular system has collateral arrangement involved predominantly by a parenchymatic sheath with isolated pericyclic fibers (figure 7).

The non-galled pinnula has positive reactions for all the analyzed compounds, except starch (tables 1-2). Proteins occur in palisade and spongy parenchyma. Reducing sugars occur in epidermis and spongy parenchyma, and lipids were detected in epidermis, non-glandular trichomes, palisade and spongy parenchyma. Lignin is detected in the walls of xylem cells and pericyclic fibers. Polyphenols occur in cells of epidermis and palisade parenchyma (figure 8); alkaloids in epidermis and terpenoids in the vascular bundles (figure 9), and in the basal cells of the unicellular non-glandular trichomes.

Anatomical and histochemical profiles of mature galls - The outer tissue compartment is formed by the epidermis, parenchyma, vascular bundles and sclerenchyma. The epidermis is uniseriate, with thick-walled elongated cells, covered by thin cuticle. Glandular and non-glandular trichomes occur (figure 10). The parenchyma has 3-4 cell layers and the sclerechyma 4-5 cell layers. The neoformed vascular bundles are collateral and immersed in the sclerechymatic layer. The inner compartment is formed by 4-5 layers of parenchymatic cells, which limits the nutritive tissue, with periclinally elongated cells (figure 11).

The histochemical profile of mature galls reveals positive results for all tested substances, except for starch (tables 1-2). Proteins occur in parenchyma cells of the outer and inner compartments, in sclerenchyma (figure 12), and in nutritive cells. Reducing sugars are detected in the ordinary epidermal cells, nonglandular trichomes, parenchymatic cells of the outer compartment (figure 13), and nutritive tissues. Lipids are detected in the epidermis, non-glandular trichomes, and parenchymatic cells of outer and inner compartments (figure 14-15), and nutritive tissue. Lignins are detected in the cell walls of the 
sclereids (figure 16). Polyphenols occur in epidermis, parenchymatic cells of the outer compartment and cytoplasm of the sclerenchyma cells (figure 17). Alkaloids occur in cells of epidermis and parenchymatic cells of the outer compartment (figure 18). Terpenoids occur in non-glandular trichomes and in cytoplasm of the sclereids (figures 19-21).

Anatomical and histochemical profiles of senescent galls - The dermal and ground system is suberized in the outer tissue compartment. The vascular system does not alter toward senescent gall. The inner compartment and nutritive tissue has necrotic

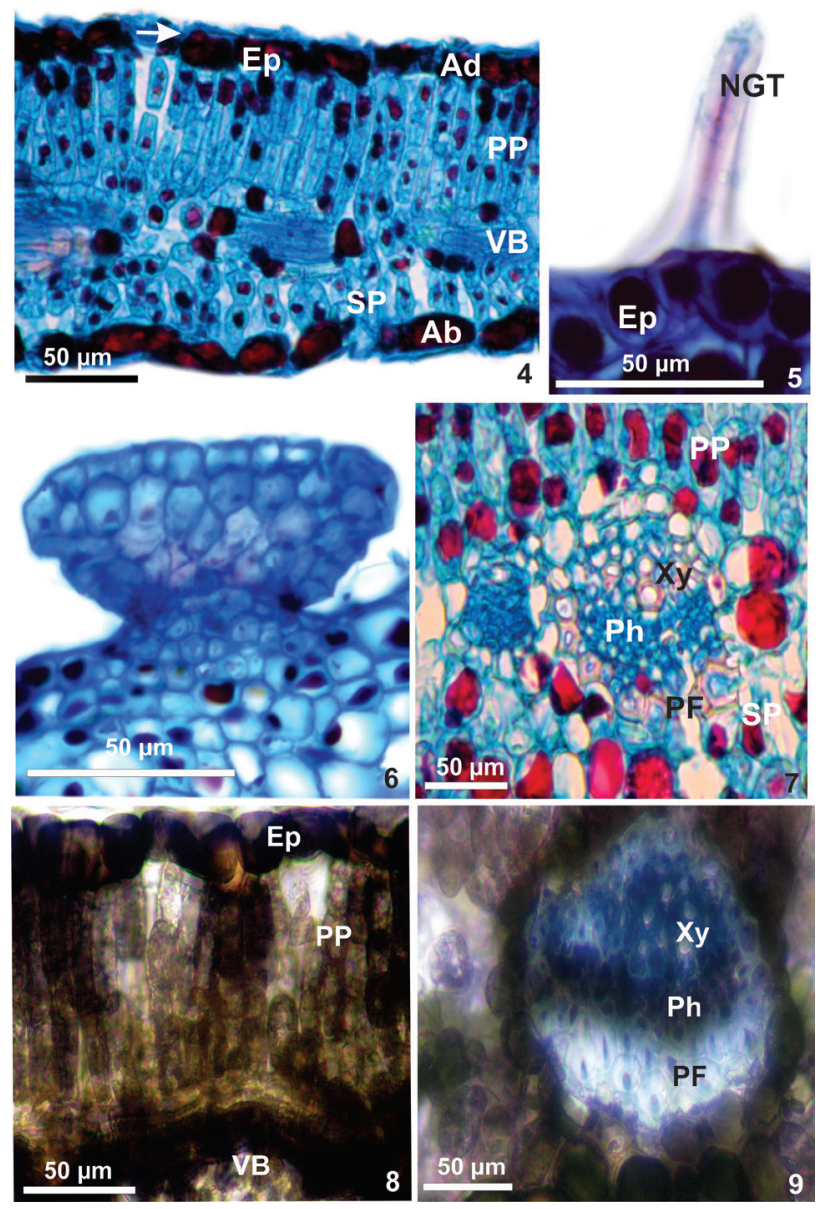

Figure 4-9. Transverse sections of the non-galled pinnulae of Mimosa tenuiflora (Leguminosae - Caesalpinioideae). 4-7. Anatomy. 4. Pinnula evidencing uniseriate epidermis covered by a thin cuticle (arrow), palisade and spongy parenchyma, and vascular bundles. 5. Non-glandular trichomes. 6. Multicellular glandular trichomes. 7. Vascular bundles evidencing xylem and phloem involved by pericyclic fibers. 8-9. Histochemistry. 8. Polyphenols detected on the epidermis and in the palisade parenchyma. 9. Terpenoids in the vascular bundles. Ad (adaxial), Ab (Abaxial), Ep (epidermis), Ph (phloem), PF (pericyclic fibers), NGT (non-glandular trichomes), PP (palisade parenchyma), SP (spongy parenchyma), VB (vascular bundles) Xy (xylem). cells. For senescent galls, the histochemical tests were positive for suberin in necrotic nutritive cells and lignins in cell walls of the sclereids (tables 1-2; figures 22-23).

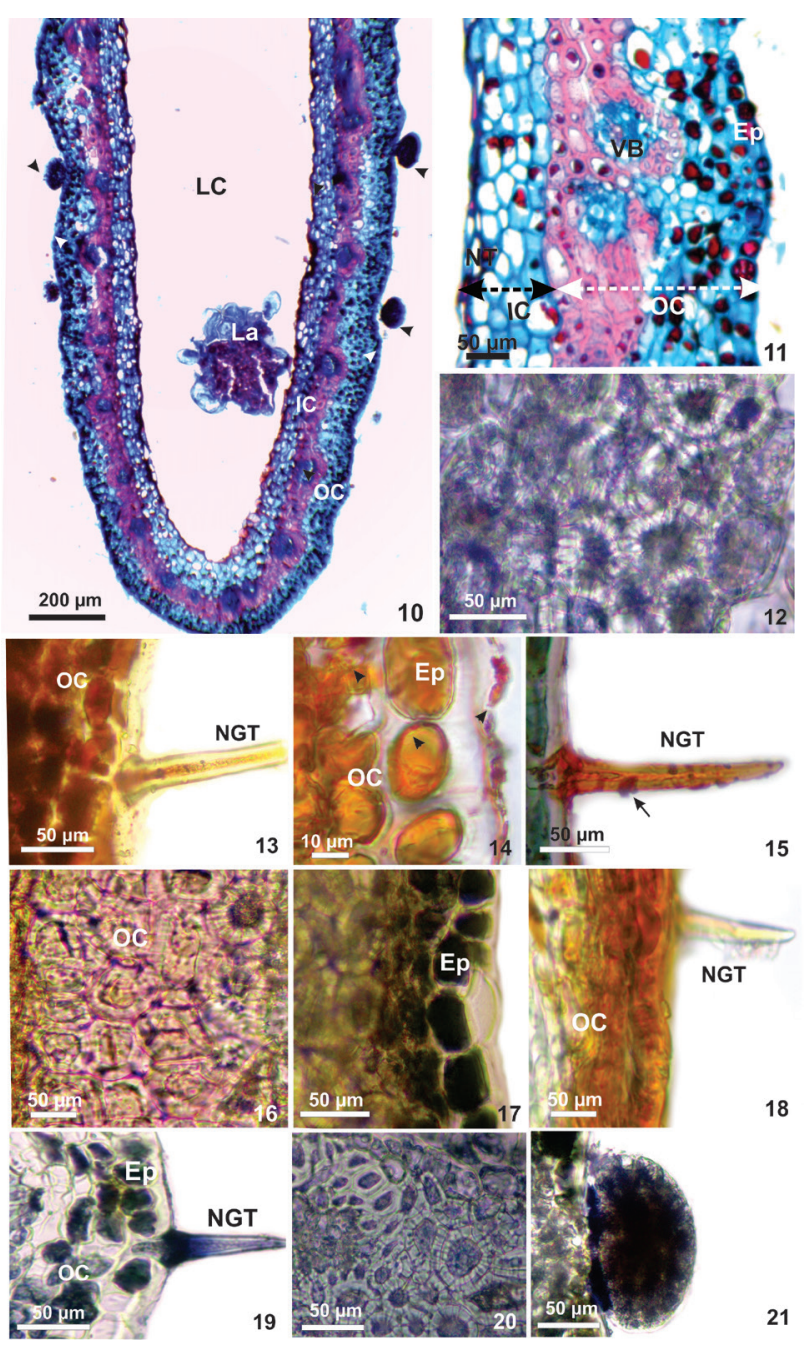

Figure 10-21. Lopesia sp. mature galls (Cecidomyiidae Diptera) on pinnulae of Mimosa tenuiflora (Leguminosae Caesalpinioideae). 10-11. Gall anatomy.10. Longitudinal section evidencing larval chamber and larva, cuticle (white arrow) and glandular trichomes (black arrow). 11-21. Transverse sections. 11. Outer and inner compartments. 12-21. Gall histochemistry. 12. Proteins detected in sclerenchyma cells. 13. Reducing sugars detected on the epidermis and in the parenchyma cells of the outer compartment. 14-15. Lipids evidencing the cuticle (black arrow) on epidermal ordinary cells and non-glandular trichomas. 16. Lignin detected on cell walls of the sclerenchyma (white arrow). 17. Polyphenols detected on the epidermis and in the cytoplasm of the sclereids. 18. Alkaloids detected on the epidermis and in the parenchyma cells of the outer compartment. 19-21. Terpenoids detected in non-glandular trichomes, cytoplasm of the sclereids, and glandular trichomes. Ep (epidermis), IC (inner compartment), LC (larval chamber), La (larva), NT (nutritive tissue), NGT (nonglandular trichomes), OC (outer compartment), VB (vascular bundles). 


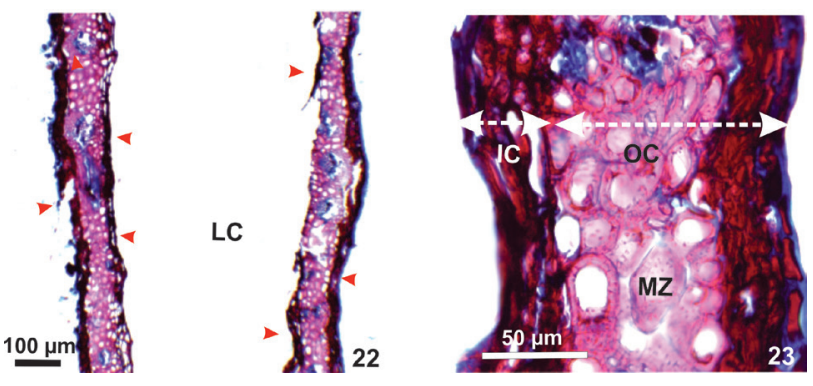

Figure 22-23. Transverse sections of Lopesia sp. senescent galls (Cecidomyiidae - Diptera) on the pinnulae of Mimosa tenuiflora (Leguminosae - Caesalpinioideae). 22. Gall evidencing necrotic cells of the epidermis and nutritive tissue (red arrow). 23. Detail of the gall evidencing accumulation of suberin in the outer compartment parenchyma, higher lignification in mechanical zone, inner compartment and nutritive tissue with necrotic cells. Ep (epidermis), IC (inner compartment), LC (larval chamber), MZ (mechanical zone), NGT (non-glandular trichomes), OC (outer compartment).

\section{Discussion}

The anatomical alterations from non-galled pinnulae toward galls - The structural alterations induced by Lopesia sp. on the pinnulae of M. tenuiflora are quite similar to those induced by other species of Cecidomyiidae in the neotropics (Arduin \& Kraus 1995, Moura et al. 2009, Oliveira \& Isaias 2009, Oliveira et al. 2010). Cecidomyiidae galls commonly have parenchyma homogenization and the formation of sclerenchyma layers adjacent to the nutrient tissue (Rohfritsch 1992). Accordingly, gall features seem to be independent of the host plant potentialities. Nevertheless, we can consider that in M. tenuifloraLopesia sp. system, the redifferentiation of an inner parenchymatic layer between the sclereids and the nutritive tissue is peculiar. Concerning the dermal

Table 1. Histochemical tests in non-galled pinnula, mature and senescent galls of Lopesia sp. (Diptera - Cecidomyiidae) on Mimosa tenuiflora (Leguminosae - Caesalpinioideae).

\begin{tabular}{lccccc}
\hline Reagents & Substances & $\begin{array}{c}\text { Non-galled } \\
\text { pinnula }\end{array}$ & $\begin{array}{c}\text { Mature } \\
\text { galls }\end{array}$ & $\begin{array}{c}\text { Senescent } \\
\text { galls }\end{array}$ & Color result \\
\hline Bromophenol blue & Proteins & + & + & - & Dark Blue \\
Ferric chloride & Polyphenols & + & + & - & $\begin{array}{c}\text { Bluish Black or dark } \\
\text { green }\end{array}$ \\
Fehling & Reducing sugars & + & + & - & Bright Red \\
Phloroglucinol & Lignins & + & + & + & Rose \\
Jeffrey & Alkaloids & + & + & - & Red brown \\
NADI & Terpenoids & + & + & - & Blue \\
Sudan red & Lipids & + & + & + & Red \\
Lugol & Starch & - & - & - & Brown \\
\hline
\end{tabular}

Results: (+) positive reaction; (-) negative reaction.

system, there is apparently no alteration in the structure of ordinary epidermal cells and trichomes, an indicative that Lopesia sp. stimuli is constrained by the morphogenetical pattern of $M$. tenuiflora. Anyhow, the galling stimuli promote the differentiation of two laminar appendages on the base of two pinnulae. These hypertrophied appendages develop the valve-like leaves peculiar of this bivalve-shaped gall.

The thin cuticle covering the gall outer epidermis may be compensated by the thick cell walls. Due to the cuticle slight thickness on M. tenuiflora - Lopesia sp. system, its primary function, i.e., protection against abiotic factors, may be performed by the thick periclinal cell walls, which can control the excess of water loss due to the high temperatures of Caatinga (Gal et al. 2015). Together with the thick cell walls, the glandular and non-glandular trichomes observed both in host pinnula and galls may enhance the protection against unfavorable environmental features (Stone \& Schonrogge 2003, Moura et al. 2009, Oliveira \& Isaias 2010). Also, gall tissues and trichomes are terpenoid-rich, which may add in chemical defense against natural enemies (Souza-Silva et al. 2017).

The neoformation of vascular bundles is a peculiarity of the galls of Lopesia sp. on M. tenuiflora. These neoformed vascular bundles are connected to the vascular system of the rachis and may transfer nutrients to the nutritive cells. Consequently, they are crucial both to the galling herbivore nutrition, and to the maintenance of gall structure (Dias et al. 2013). The collateral bundles are common for Cecidomyiidae galls (Arduin \& Kraus 1995, Oliveira \& Isaias 2009, 
Table 2. Histolocalization of metabolites in the non-galled pinnulae of Mimosa tenuiflora (Leguminosae - Caesalpinioideae) and galls of Lopesia sp. (Diptera - Cecidomyiidae).

\begin{tabular}{|c|c|c|c|c|c|c|c|}
\hline Histolocalization & Protein & Lipids & $\begin{array}{l}\text { Reducing } \\
\text { sugars }\end{array}$ & Polyphenols & Terpenoids & Alkaloids & Lignin \\
\hline \multicolumn{8}{|l|}{ Non-galled tissues } \\
\hline Epidermis & - & + & + & + & - & + & - \\
\hline Non-glandular trichomes & - & + & - & - & + & - & - \\
\hline Palisade parenchyma & + & + & + & + & - & - & - \\
\hline Spongy parenchyma & + & + & + & - & - & - & - \\
\hline Vascular bundle & - & - & - & - & + & - & + \\
\hline Pericyclic fibers & - & - & - & - & - & - & + \\
\hline \multicolumn{8}{|l|}{ Mature galls } \\
\hline \multicolumn{8}{|l|}{ Outer compartment } \\
\hline Epidermis & - & + & + & + & - & + & - \\
\hline Non-glandular trichomes & - & + & + & - & + & - & - \\
\hline parenchyma & + & + & + & + & - & + & - \\
\hline Sclerenchyma & + & - & - & + & + & - & + \\
\hline \multicolumn{8}{|l|}{ Inner compartment } \\
\hline parenchyma & + & + & + & - & - & - & - \\
\hline Nutritive tissue & + & + & + & - & - & - & - \\
\hline \multicolumn{8}{|l|}{ Senescent galls } \\
\hline \multicolumn{8}{|l|}{ Outer compartment } \\
\hline Epidermis & - & + & + & - & - & + & - \\
\hline Non-glandular trichomes & - & + & - & - & - & - & - \\
\hline Parenchyma & - & + & - & - & - & - & - \\
\hline Sclerenchyma & + & - & - & - & - & - & + \\
\hline \multicolumn{8}{|l|}{ Inner compartment } \\
\hline Parenchyma & - & + & - & - & - & - & - \\
\hline Nutritive tissue & - & - & - & - & - & - & - \\
\hline
\end{tabular}

Results: (+) positive reaction; (-) negative reaction.

2010, Fleury et al. 2015), and have been previously reported for the galls on Copaifera langsdorffii Desf. (Oliveira \& Isaias 2009, 2010) and Aspidosperma spruceanum Benth. ex Müell. Arg. (Formiga et al. 2011) in Neotropical region.

Due to gall stimuli, the ground system reassumes its potential meristematic capacity for cell division and hypertrophy (Moura et al. 2009, Oliveira \& Isaias 2010). Cell divisions occur in several and distinct planes at gall site, which result in the increased number of cell layers. Hyperplasia and cell hypertrophy are common phenomena in gall development, and have been already reported for several host plantgalling herbivore systems (Moura et al. 2008, Moura et al. 2009, Fleury et al. 2015). The ground system of the galls on $M$. tenuiflora is altered from the pinnula palisade and spongy parenchyma toward the homogenous parenchyma, similar to the galls induced by Cecidomyiidae on $C$. langsdorffii (Oliveira et al. 2010) and Lantana camara L. (Moura et al. 2008). On the galls of Lopesia sp. on M. tenuiflora, the homogeneous parenchyma of the outer and inner compartments may help avoiding desiccation, as large cells, with diminutive intercellular spaces may efficiently accumulate water (Kraus 2009). Accordingly, gall tissue compartments in Lopesia sp. galls may help tolerating the hydric stress of the Caatinga. 
Cecidomyiidae galls commonly have hypertrophied parenchymatic cells, and the development of a mechanical layer around the nutritive tissue (Rohfritsch 1992). Lignin accumulation may be stimulated by biotic stresses, such as the attack of pathogens, or abiotic stresses, such as water deficit (Lee et al. 2007). The over accumulation of lignin on Lopesia sp. galls proved the deviation of secondary metabolites, commonly produced by the host plant toward neo-formed tissue layers, due to the biotic stress imposed by the larvae (Oliveira et al. 2017). Moreover, lignification can also confer protection against natural enemies on Lopesia sp. galls (Mani 1964, Stone \& Schönrogge 2003).

As is true for most Cecidomyiidae galls, Lopesia sp. altered the innermost portions of the ground system toward its nutritive demands. The nutritive cells are consumed by the larvae, and quickly differentiate and divide continuously. The nutritive tissue has small cells when compared to the other gall tissues, similarly to the leaf galls induced by Pisphondylia brasiliensis Couri and Maia, 1992 (Cecidomyiidae) on Guapira opposita (Vell.) Reitz. (Nyctaginaceae) (Fleury et al. 2015) and by Lopesia sp. on Lonchocarpus cultratus (Vell.) Azevedo-Tozzi \& H.C.Lima (LeguminosaePapilionoideae) (Suzuki et al. 2015). In Lopesia sp. galls, nutritive cells accumulate lipids and proteins, with poor accumulation of defensive substances, as reported for other galls (Hartley 1998).

The cells of the outer and inner parenchyma of Lopesia sp. galls on M. tenuiflora get through a process of suberization after the emergence of the galling insect, which may protect the galling site from the invasion of pathogens (Isaias \& Oliveira 2012). The suberization repeats a morphogenetical pattern present in other sites of the host plant, which is activated in gall final phase. Such expression of a plant potentiality in an uncommon site is not exclusive of Cecidomyiidae galls, as it has been described in galls induced by Aceria lantanae Cook (Acari) on Lantana camara L. (Moura et al. 2009) and by Callophya duvauae Scott (Psylloidea) on Schinus polygamus (Cav.) Cabrera (Dias et al. 2013).

The histochemical profile in gall tissue compartments The activity of Lopesia sp. does not prevent or induce the neo-synthesis of any chemical compounds histochemically detected in the non-galled pinnula of M. tenuiflora. However, metabolites detection in specific gall sites can be a result of the manipulation of the chemical composition of the host plant by the galling insect (Nyman \& Julkunen-Tiito 2000).
Lipids accumulate both in non-galled tissues and galls outer and inner tissue compartment, which indicates the maintenance of a host plant capability. Lipids are high energetic molecules (Buchanan et al. 2000), which can be converted into structural and metabolic components, as proposed for Lonchocarpus muehlbergianus Hassl. (Leguminosae-Papilionoideae) due to the activity of Euphalerus ostreoides Crawf. (Oliveira et al. 2006). Such accumulation is important for the maintenance and development of Lopesia sp. galls.

Proteins and reducing sugars accumulate in the parenchymatic layers of the outer and inner compartment in mature galls, which indicates that these metabolites are not only related to galling nutrition. Both proteins and reducing sugars can be translocated from the outer toward the inner tissue compartment, conferring resources for the development of the structure (Schrönrogge et al. 2000, Raman 2007), and reallocation to the nutritive cells (Oliveira et al. 2010, 2011) of Lopesia sp. galls on M. tenuiflora.

The accumulation of polyphenols in gall cells is usual for some Cecidomyiidae galls (Formiga et al. 2009, Nyman \& Julkunen-Tiitto 2000, Bedetti et al. 2014, 2017), and has been related to chemical defense, possibly by inhibiting oviposition and feeding of natural enemies (Oliveira et al. 2006, Moura et al. 2008). The enhancement of phenolics accumulation may also be a response to abiotic factors, such as insolation and low pluviosity (Formiga et al. 2009). As the stress of high insolation and low pluviosity is characteristic of the Caatinga environment, phenolics accumulation may be important for adjusting the microenvironment of the gall both for the host plant and for Lopesia sp. galls. The accumulation of polyphenols, terpenes and alkaloids, restricted to the outer tissue compartment in galls, may enhance the potential chemical protection (Nyman \& JulkunenTiitto 2000; Amorim et al. 2017, Silva et al. 2017) in the galls of Lopesia sp. on M. tenuiflora.

\section{Conclusion}

The reorganization and compartmentalization of the tissues in gall developmental site resemble mostly those already described for Cecidomyiidae galls, but the parenchyma layers of the inner compartment between the mechanical zone and the nutritive tissue is a peculiarity of Lopesia sp. galls on M. tenuiflora. The histochemical profile of the gall is similar to that of its 
host plant, and the secondary metabolites are restricted to the outer compartment. Therefore, we assume that the polyphenol accumulation may help gall establishment, by avoiding the excess of light irradiation and low pluviosity. Even though the Caatinga environment does not seem to impose a special constraint for Lopesia sp. gall development, the thick periclinal cell walls and the homogeneous parenchyma may contribute to the control of humidity and light radiation, protecting the galling insect against the dry environment.

\section{Acknowledgments}

The authors thank Fundação de Amparo à Pesquisa do Estado da Bahia (FAPESB) for the scholarships conferred to the first author through PIBIC/UNEB (Programa Institucional de Bolsas de Iniciação Científica), Fundação de Amparo à Pesquisa de Minas Gerais (FAPEMIG), CAPES, CNPq (307011/2015-1; 406111/2016-2) and FAPESB (FAPESB 9648/2015) for financial support, and three anonymous reviewers for their valuable contributions.

\section{Literature cited}

Amorim, D. O., Ferreira, B. G. \& Fleury, G. 2017. Plant potentialities determine anatomical and histochemical diversity in Mikania glomerata Spreng. galls. Revista Brasileira de Botânica 40: 517-527.

Arduin, M. \& Kraus, J.E. 1995. Anatomia e Ontogenia de galhas foliares de Piptadenia gonoacantha (Fabales, Mimosaceae). Boletim de Botânica da Universidade de São Paulo 14: 109-130.

Arya, H.C., Vyas, G.S. \& Tandon, P. 1975. The problem of tumor formation in plants. In: H.Y. Mohan Ram, J.J. Shah \& C.K. Shah, (eds.). Form, structure and function in plants (Prof. B.M. Johri commemoration volume). Sarita Publishers, India, pp. 270-279.

Backer, J.R. 1958. Note on the use of bromophenol blue for the histochemical recognition of protein. Quarterly Journal of Microscopical Science 99: 459-460.

Bedetti, C.S., Modolo, L.V. \& Isaias, R.M.S. 2014. The role of phenolics in the control of auxin in galls of Piptadenia gonoacantha (Mart.) MacBr (Fabaceae:Mimosoideae). Biochemical Systematics and Ecology 55: 53-59.

Bedetti, C.S., Bragança, G.P. \& Isaias, R.M.S. 2017. Influence of auxin and phenolic accumulation on the patterns of cell differentiation in distinct gall morphotypes on Piptadenia gonoacantha (Fabaceae). Australian Journal of Botany 65: 411-420.

Bragança, G.P., Oliveira, D.C. \& Isaias, R.M.S. 2017. Compartimentalization of metabolites and enzymatic mediation in nutritive cells of Cecidomyiidae galls on Piper arboretum Aubl. (Piperaceae). Journal of Plant Studies 6: 11-22.
Brundett, M.C., Kendrick, B. \& Peterson, C.A. 1991. Efficient lipid staining in plant material with Sudan red 7B or fluoral yellow 088 in polyethylene glycolglycerol. Biotechnic \& Histochemistry 66: 111-116.

Buchanan, B.B., Gruissen, W. \& Jones, R.L. 2000. Biochemistry and molecular biology of plants. Rockville: American Society of Plant Physiologists.

Burrows, G.E. 2001. Comparative anatomy of the photosynthetic organs of 39 xeromorphic species from subhumid New South Wales, Australia. International Journal Plant Science 162: 411-430.

Carvalho-Fernandes, S.P., Almeida-Cortez, J.S., Ferreira, A.L.N. 2012. Riqueza de galhas entomógenas em áreas antropizadas e preservadas de caatinga. Revista Árvore, Viçosa 36: 269-277.

David, R. \& Carde, J.P. 1964. Coloration defférentielle des inclusions lipidiques et terpeniques des pseudophylles du Pin maritime au moyen du réactif Nadi. Comptes Rendus Hebdomadaires des Séances de l'Académic des Sciences 258: 1338-1340.

Dias, G.G., Moreira, G.R.P., Ferreira, B.G. \& Isaias, R.M.S. 2013. Developmental pathway from leaves to galls induced by a sap-feeding insect on Schinus polygamus (Cav.) Cabrera (Anacardiaceae). Anais da Academia Brasileira de Ciências 85: 187-200.

Espírito-Santo, M.M. \& Fernandes, G.W. 2007. How many species of gall-inducing insects are there on earth, and where are there? Annals of the Entomological Society of America 100: 95-99.

Fahmy, G.M. 1997. Leaf anatomy and its relation to the ecophysiology of some non-succulent desert plants from Egypt. Journal of Arid Environments 36: 499-525.

Fahn, A. \& Cutler, D.F. 1992. Xerophytes. Gebüder Borntraeger, Berlin.

Fleury, G., Ferreira, B.G., Soares, G.L.G., Oliveira, D.C. \& Isaias, R.M.S. 2015. Elucidating the determination of the rosette galls induced by Pisphondylia brasiliensis Couri and Maia 1992 (Cecidomyiidae) on Guapira opposita (Nyctaginaceae). Australian Journal of Botany 63: 608-617.

Formiga, A.T., Gonçalves, S.J.M.S., Soares, G.L.G. \& Isaias, R.M.S. 2009. Relações entre o teor de fenóis totais e o ciclo das galhas de Cecidomyiidae em Aspidosperma spruceanum Müll.Arg. (Apocynaceae). Acta Botanica Brasilica 23: 93-99.

Formiga, A.T., Soares, G.L.G. \& Isaias, R.M.S. 2011. Responses of the host plant tissues to gall induction in Aspidosperma spruceanum Müell. Arg. (Apocynaceae). American Journal of Plant Sciences 2: 823-834.

Gagné, R.J. \& Jaschhof, M. 2017. A Catalog of the Cecidomyiidae (Diptera) of the World. 3 Edition, Digital v. 2, Washington, USA.

Gall, H.L., Philippe, F., Domom, J.M., Gilllet, F., Pelloux, J., Rayon, C. 2015. Cell wall metabolism in response to abiotic stress. Plants (Basel) 4: 112-166.

Harper, L.J., Schönrogge, K., Lim, K.Y., Francis, P. \& Lichtenstein, C.P. 2004 Cynipid galls: insect-induced modifications of plant development create novel plant organs. Plan cell environ 27: 327-335. 
Hartley, S.E. 1998. The chemical composition of plant galls: are levels of nutrients and secondary compounds controlled by the gall-former? Oecologia 113: 492-501.

Isaias, R.M.S. \& Oliveira, D.C. 2012. Gall phenotypesproduct of plant cells defensive responses to the inducers attack. In: J.M. Mérillon \& K.G. Ramawat (eds.). Plant Defense: Biological Control. Progress in Biological Control, pp. 273-290.

Isaias, R.M.S., Oliveira, D.C. \& Carneiro, R.G.S. 2011. Role of Euphalerus ostreoides (Hemiptera: Psylloidea) in manipulating leaflet ontogenesis of Lonchocarpus muehlbergianus (Fabaceae). Botany 89: 581-592.

Johansen, D.A. 1940. Plant microtechnique. Mac GrawHill Book Inc., New York.

Kraus, J.E. 2009. Galhas: morfogênese, relações ecológicas e importância econômica. In: M.L TissotSqualli (ed.). Interações Ecológicas \& Biodiversidade. Unijuí, Ijuí, pp. 109-140.

Kraus, J.E. \& Arduin, M. 1997. Manual Básico de Métodos em Morfologia Vegetal. Rio de Janeiro, Seropédica.

Lee, B., Kim, K., Jung, W., Avice, J., Ourry, A. \& Kim, T. 2007. Peroxidases and lignification in relation to the intensity of water-deficit stress in white clover (Trifolium repens L.). Journal of Experimental Botany 58: 1271-1279.

Maia, V.C., Fernandes, G.W., Magalhães, H. \& Santos, J.C. 2010. Two new species of Lopesia Rübsaamen (Diptera, Cecidomyiidae) associated with Mimosa hostilis (Mimosaceae) in Brazil. Revista Brasileira de Entomologia 54: 578-583.

Mani, M.S. 1964. Ecology of Plant Galls. The Hague, Junk.

Moura, M.Z.D., Soares, G.L.G. \& Isaias, R.M.S. 2008. Species-specific changes in tissue morphogenesis induced by two arthropod leaf gallers in Lantana camara L. (Verbenaceae). Australian Journal of Botany 53: 153-160.

Moura, M.Z.D., Soares, G.L.G \& Isaias, R.M.S. 2009. Ontogênese da folha e das galhas induzidas por Aceria lantanae Cook (Acarina: Eriophyidae) em Lantana camara L. (Verbenaceae). Revista Brasileira de Botânica 32: 271-282.

Nyman, T. \& Julkunen-Tiitto R. 2000. Manipulation of the phenolic chemistry of willows by gall-inducing sawflies. Proceedings of the National Academic of Sciences of the United States of America 97: 13184-13187.

Oliveira, D.C. \& Isaias, R.M.S. 2009. Influence of leaflet age in anatomy and possible adaptive values of the gall of Copaifera langsdorffii (Fabaceae: Caesalpinioideae). Revista de Biologia Tropical 57: 293-302.

Oliveira, D.C. \& Isaias, R.M.S. 2010. Redifferentiation of leaflet tissues during gall midrib gall development in Copaifera langsdorffi (Fabaceae). South African Journal of Botany 76: 239-248.

Oliveira, D.C., Christiano, J.C.S., Soares, G.L.G. \& Isaias, R.M.S. 2006. Reações de defesas químicas e estruturais de Lonchocarpus muehlbergianus Hassl. (Fabaceae) à ação do galhador Euphalerus ostreoides Crawf. (Hemiptera: Psyllidae). Revista Brasileira de Botânica 29: 657-667.
Oliveira, D.C., Carneiro, R.G.S., Magalhães, T.A. \& Isaias, R.M.S. 2011. Cytological and histochemical gradients on two Copaifera langsdorffii Desf. (Fabaceae) - Cecidomyiidae gall systems. Protoplasma 248: 829-837.

Oliveira, D.C., Magalhães, T.A., Carneiro, R.G.S., Alvim, M.N, \& Isaias, R.M.S. 2010. Do Cecidomyiidae galls of Aspidosperma spruceanum (Apocynaceae) fit the pre-established cytological and histochemical patterns? Protoplasma 242: 81-93.

Oliveira, D.C., Moreira, A.S.F.P., Isaias, R.M.S., Martini, V. \& Rezende, U.C. 2017. status and photosynthetic rate of the leaflet galls induced by Bystracoccus matayba (Eriococcidae) on Matayba guianensis (Sapindaceae). Frontiers in Plant Science 8: 1-12.

Raman, A. 2007. Insect-induced plant galls of India: unresolved questions. Current Science 92: 748-757.

Rohfritsch, O. 1992. Patterns in Gall Development. In: J.D. Shorthouse \& O. Rohfritsch. Biology of insect-induced galls (eds.). Oxford University Press, New York.

Rotondi, A., Rossi, F., Asunis, C. \& Cesaraccio, C. 2003. Leaf xeromorphic adaptations of some plants of a coastal Mediterranean macchia ecosystem. Journal Mediterranean Ecology 4: 25-35.

Sass, J.E. 1951. Botanical Microtechnique. 2 ed. Iowa State College Press, Ames.

Santos, J.C., Almeida-Cortez, J.S. \& Fernandes, G.W. 2011. Richness of gall-inducing insects in the tropical dry forest (caatinga) of Pernambuco. Revista Brasileira de Entomologia 55: 45-54.

Santos-Silva, J., Simon, M.F. \& Tozzi, A.M.G.A. 2015. Revisão taxonômica de Mimosa ser. Leiocarpae sensu lato (Leguminosae-Mimosoideae). Rodriguésia 66: 95-154.

Schrönrogge, K., Harper, L.J \& Lichtenstein, C.P. 2000. The protein content of tissues in cynipid galls (Hymenoptera: Cynipidae): Similarities between cynipid galls and seeds. Plant, Cell and Environment 23: 215-222.

Souza-Silva, E.A., Saboia, G. Jorge, N.C., Hoffmann, C., Isaias, R.M.S., Soares, G.L.G. \& Zini, C.A. 2017. Development of a HS-SPME-GC/MS protocol assisted by chemometric tools to study herbivore-induced volatiles in Myrcia splendens. Talanta 175: 9-20.

Stone, G.N \& Schonrogge, K. 2003. The adaptive significance of insect gall morphology. Trends in Ecology and Evolution 18: 512-522.

Suzuki, A.Y.M., Bedetti, C.S., \& Isaias, R.M.S. 2015. Detection and distribution of cell growth regulators and cellulose microfibrils during the development of Lopesia sp. galls on Lonchocarpus cultratus (Fabaceae). Botany 93: 435-444. 